\title{
The 16p11.2 Deletion Mouse Model of Autism Exhibits Altered Cortical Progenitor Proliferation and Brain Cytoarchitecture Linked to the ERK MAPK Pathway
}

\author{
[Joanna Pucilowska, Joseph Vithayathil, Emmanuel J. Tavares, Caitlin Kelly, J. Colleen Karlo, and Gary E. Landreth \\ Department of Neurosciences, Case Western Reserve University, Cleveland, Ohio 44106-4928
}

\begin{abstract}
Autism spectrum disorders are complex, highly heritable neurodevelopmental disorders affecting $\sim 1$ in 100 children. Copy number variations of human chromosomal region 16p11.2 are genetically linked to $1 \%$ of autism-related disorders. This interval contains the MAPK3 gene, which encodes the MAP kinase, ERK1. Mutations in upstream elements regulating the ERK pathway are genetically linked to autism and other disorders of cognition including the neuro-cardio-facial cutaneous syndromes and copy number variations. We report that a murine model of human 16p11.2 deletion exhibits a reduction in brain size and perturbations in cortical cytoarchitecture. We observed enhanced progenitor proliferation and premature cell cycle exit, which are a consequence of altered levels of downstream ERK effectors cyclin D1 and p27 ${ }^{\text {Kip } 1}$ during mid-neurogenesis. The increased progenitor proliferation and cell cycle withdrawal resulted in premature depletion of progenitor pools, altering the number and frequency of neurons ultimately populating cortical lamina. Specifically, we found a reduced number of upper layer pyramidal neurons and an increase in layer VI corticothalamic projection neurons, reflecting the altered cortical progenitor proliferation dynamics in these mice. Importantly, we observed a paradoxical increase in ERK signaling in mid-neurogenesis in the 16p11.2del mice, which is coincident with the development of aberrant cortical cytoarchitecture. The 16p11.2del mice exhibit anxiety-like behaviors and impaired memory. Our findings provide evidence of ERK dysregulation, developmental abnormalities in neurogenesis, and behavioral impairment associated with the $16 p 11.2$ chromosomal deletion.
\end{abstract}

Key words: autism; cortex; cortical development; ERK; MAP kinases; mouse models

\section{Introduction}

Recurrent copy number variations (CNVs) are genetically linked to neuropsychiatric disorders, autism, and schizophrenia (Levy et al., 2011; Sanders et al., 2011). 16p11.2 chromosomal deletions provide one of the most common genetic linkages to autism, whereas duplications are linked to schizophrenia (Kumar et al., 2008; Weiss et al., 2008; McCarthy et al., 2009; Fernandez et al., 2010). Individuals with 16p11.2 CNV exhibit a wide range of clinical symptoms, including developmental and language delay, cognitive impairment, stereotypies, and obesity. The consequences of deletions are more severe than duplications, a finding reproduced in newly developed murine models in which the region corresponding to the human16p11.2 locus is deleted or duplicated (Horev et al., 2011; Portmann et al., 2014).

Developmental defects affecting the cerebral cortex play pivotal roles in many human disorders, including autism spectrum disorders (ASDs). Perturbation in proliferation and neurogenesis

\footnotetext{
Received Nov. 18, 2013; revised Jan. 6, 2015; accepted Jan. 9, 2015.

Author contributions: G.E.L. and J.P. designed research; J.P., E.J.T., C.K., and J.C.K. performed research; J.P. and E.J.T. analyzed data; J.P. and J.V. wrote the paper.

This work was supported by Simons Foundation Grant SFARI 275316 to G.E.L.

The authors declare no competing financial interests.

Correspondence should be addressed to Dr. Gary E. Landreth, Alzheimer Research Laboratory E649, Department of Neurosciences, School of Medicine, Case Western Reserve University, 10900 Euclid Avenue, Cleveland, OH 441064928. E-mail: gel2@case.edu.

DOI:10.1523/JNEUROSCI.4864-13.2015

Copyright $\odot 2015$ the authors $\quad 0270-6474 / 15 / 353190-11 \$ 15.00 / 0$
}

alter cortical microcircuitry, leading to the pathology observed in these syndromes (Courchesne et al., 2007). Therefore, it is important to understand the basic molecular mechanisms subserving the formation of normal cortical circuitry.

The extracellular signal-regulated kinases, ERK1 and ERK2, are the central elements of one of the most prominent intracellular signaling pathways governing neural development and synaptic plasticity (Adams and Sweatt, 2002; Newbern et al., 2008). The ERKs are genetically linked to ASDs, neuro-cardio-faciocutaneous syndromes (RASopathies), and other disorders of cognition (Kalkman, 2012; Rauen, 2013). Importantly, recent analysis clearly links the MAPK pathway to functional gene networks affected in ASDs (Pinto et al., 2014). The ERKs play critical roles in corticogenesis by regulating cell cycle in proliferating neural progenitors (Pucilowska et al., 2012). We previously reported that genetic ablation of the ERKs results in altered brain cytoarchitecture and physiological deficits (Samuels et al., 2008; Pucilowska et al., 2012). A broad range of data demonstrates that ERK1/2 govern multiple stages of brain development and maturation and are independently associated with developmental disorders hallmarked by aberrant brain cytoarchitecture and intellectual disability (Schubbert et al., 2007; Nakamura et al., 2009; Tartaglia and Gelb, 2010; Pucilowska et al., 2012). A mouse model of the human 16p11.2 microdeletion (the chr7qF3deficient mouse, termed 16p11.2del) recapitulates some of the ASD pathology (Horev et al., 2011; Portmann et al., 2014). How- 
ever, the potential mechanisms linking the genetic deletion in mice to the underlying ASD pathophysiology are unknown. Therefore, we systematically evaluated the $16 p 11 \mathrm{del}$ mice for perturbations in brain development, providing evidence that the behavioral changes in these mice may be at least partially caused by ERK-influenced defects in cortical neurogenesis. The 16p11.2 locus contains 27 genes, including the ERK1 gene (MAPK3) and the Major Vault Protein (MVP) gene. MVP is postulated to act as an ERK scaffold that modulates ERK signaling (Kolli, 2004; Liang et al., 2010). We previously detected ASD-related phenotypes in mice lacking ERK1/2 (Selcher et al., 2001; Pucilowska et al., 2012). We report that the 16p11.2del mice exhibit elevated ERK activity in the developing cortex and hippocampus and altered progenitor proliferation, resulting in abnormal cortical cytoarchitecture. Our data suggest that the pathophysiology observed in 16p11.2del mice correlates with dysregulation of ERK signaling, which may underlie the ASD-related endophenotypes.

\section{Materials and Methods}

Mice. The 16p11.2 deletion mice were previously described by Mills and colleagues (Horev et al., 2011) and were purchased from The Jackson Laboratory. The mice have been backcrossed for 8 generations to the C57BL/6N background by The Jackson Laboratory. For timed pregnancies, the day of vaginal plug was designated as 0.5 (E0.5). Experiments were performed in accordance with the Case Western Reserve University Institutional Animal Care and Use Committee.

Immunohistochemistry (IHC). The embryonic brains were dissected in cold PBS and fixed by immersion in $4 \%$ PFA for $1 \mathrm{~h}$ or overnight at $4^{\circ} \mathrm{C}$. Postnatal mouse brains were fixed in $4 \%$ PFA in PBS at $4^{\circ} \mathrm{C}$ overnight and serially incubated in $10 \%, 20 \%$, and $30 \%$ sucrose. The brains were sectioned $(10 \mu \mathrm{m})$, then rehydrated in PBS for $10 \mathrm{~min}$. Antigen retrieval using $1 \times$ Reveal Decloaker (Biocare) was performed for $10 \mathrm{~min}$ at $95^{\circ} \mathrm{C}$. Sections were blocked in 10\% (embryonic) and 2\% (postnatal) normal goat or donkey serum for $1 \mathrm{~h}$ at room temperature with $0.1 \%(\mathrm{v} / \mathrm{v})$ Triton $\mathrm{X}-100$ in PBS. Slides were incubated with primary antibodies overnight at $4^{\circ} \mathrm{C}$, rinsed with $\mathrm{PBS}$, and incubated with corresponding secondary antibodies for $1-2 \mathrm{~h}$ at room temperature. The primary antibodies used were as follows: polyclonal rabbit anti-pERK (Cell Signaling Technology, 1:100), rabbit polyclonal anti-Pax6 (Covance, 1:300), mouse anti-PH3 (Millipore, 1:250), rabbit anti-PH3 (Millipore, 1:500), rabbit anti-Tbr1 (Millipore Bioscience Research Reagents,1:1000), rabbit antiTbr2 (1:300), chicken anti-Tbr2 (1:250), goat anti-Brn1 (Santa Cruz Biotechnology, 1:50), rat anti-Ctip2 (Abcam, 1:500), rabbit anti-Cux1 (Santa Cruz Biotechnology, 1:100), and mouse anti-SatB2 (Abcam, 1:100). Secondary antibodies used were AlexaFluor-488 (1:1000), -546 or -593 (1:1000) conjugated to goat or donkey anti-mouse, anti-rabbit, or antigoat (Invitrogen). DNA was stained with DAPI for 5 min (Invitrogen).

Anatomically matched sections of littermate control and mutant mice were analyzed. At least 3 sections per animal were analyzed alongside the rostrocaudal axis of the dorsal telencephalon. Embryonic coronal sections were evaluated at the level of the mid-ganglionic eminences and analyzed at medial and lateral positions by counting all cells in designated $100-\mu \mathrm{m}$-wide boxes. For the PH3 counts, the dorsal ventricular zone (VZ) and subventricular zone (SVZ) were separated from the ventral telencephalon visually using well-defined anatomical markers. All $\mathrm{PH} 3^{+}$ cells were manually counted in the entire cortical primordium from cortical hem (medially) through palial-subpalial boundary. Quantification was performed blind to genotype as previously described (Glickstein et al., 2009). We counted at least three consecutive tissue slices per slide and at least four slides per animal.

In postnatal brains, coronal sections were used to count cells in 400 $\mu \mathrm{m}$ boxes in somatosensory cortex. Slides were picked at random, and the investigator was blinded to genotypes during analyses.

Analysis of cellular proliferation. Mice were injected intraperitoneally with a single dose of BrdU (50 mg/kg, Sigma-Aldrich, B5002) at E13.5 and killed exactly $24 \mathrm{~h}$ later. Anatomically matched sections were processed for IHC with anti-BrdU and anti-Ki67 antibodies (rat-anti-BrdU;
1:100, Abcam), or mouse anti-BrdU (1:100, BD Biosciences). Cell cycle exit was established by counting all $\mathrm{BrdU}^{+}$but $\mathrm{Ki}^{-} 7^{-}$cells over the total number of BrdU ${ }^{+}$cells per $100 \mu \mathrm{m}$ cortical sections of dorsomedial and dorsolateral telencephalon at E14.5. The percentage of $\mathrm{BrdU}^{+} / \mathrm{KI}_{67}$ cells was reported.

The kinetics of progenitor proliferation and postnatal neuron generation were evaluated using a pulse-chase protocol in which pregnant dams were given a single BrdU injection at E14.5 and embryos were fixed and colabeled with a lamina-specific marker at postnatal day 2 (P2).

Microscopy and image analysis. All images were acquired with a Zeiss LSM 510 confocal laser microscope equipped with argon and heliumneon lasers and analyzed with LCS confocal software, Prism, and Photoshop (Adobe). Images were collected approximately at the midpoint between the top and bottom of the two planes of focus. All counts were performed on coded sections, and Student's $t$ test was used to establish statistical significance for each experiment.

Western analysis. Cortical lysates were prepared from of E14.5 embryos and carefully dissected and washed with ice-cold HBSS. The samples were sonicated in lysis buffer (20 mu Tris, pH 7.5, $150 \mathrm{~mm} \mathrm{NaCl}, 1 \%$ NP-40, 10\% glycerol, 1 mM EDTA, $1.5 \mathrm{~mm} \mathrm{MgCl}_{2}, 20 \mathrm{~mm} \mathrm{NaF}$, and 20 $\mathrm{mm} \beta$-glycerophosphate) in the presence of protease inhibitors $(1 \mu \mathrm{g} / \mathrm{ml}$ leupeptin, $1 \mu \mathrm{g} / \mathrm{ml}$ aprotinin, $1 \mathrm{~mm}$ PMSF, and $1 \mathrm{~mm} \mathrm{Na}_{3} \mathrm{VO}_{4}$ ). Lysates were centrifuged, and protein concentrations were determined using the bicinchoninic acid assay (Pierce) with BSA as a standard. Equal amounts of protein were boiled in sample buffer, separated on SDS-PAGE gels, and transferred to Immobilon-P polyvinylidene difluoride membranes (Millipore). Membranes were blocked in 3\% BSA or 5\% skim-milk powder for $\beta$-tubulin (Santa Cruz Biotechnology) in TBS and 0.1\% Tween 20 (TBS-T) for $2 \mathrm{~h}$ at room temperature and incubated with primary antibodies overnight at $4^{\circ} \mathrm{C}$. The primary antibodies used were as follows: rabbit anti-pERK (Cell Signaling Technology, 1:1000), mouse anti-ERK2 (BD Biosciences Discovery Labware, 1:3000), mouse anti-ERK1 (Zymed Laboratories, 1:1000), and anti- $\beta$-tubulin (1:5000; Santa Cruz Biotechnology). Membranes were washed with TBS-T, incubated with HRPconjugated secondary antibodies: goat anti-mouse or anti-rabbit (1: 5000; GE Healthcare) in TBS-T with $5 \%$ milk for $2 \mathrm{~h}$ at room temperature. Detection was performed using Millipore chemiluminescence using BioMax MR x-ray film (Eastman Kodak). Densitometry was performed using Adobe Photoshop histogram function, and statistical analysis was done with GraphPad Prism software.

Behavioral analysis. Three-month-old male mice were tested using standardized behavioral analyses, including the elevated plus maze, open-field, novel object recognition test, and 3-chamber social interaction assay. Tests were performed in the sequence listed. All testing was performed in the designated behavior room during the light cycle between 9:00 A.M. and 6:00 P.M. A maximum of 5 mice were housed together with ad libitum access to food and water with a $12 \mathrm{~h}$ light/dark cycle. All equipment used during the testing was cleaned with $70 \%$ ethanol after each use to remove odor cues. The tester was blinded to the genotype of each animal. All tests were performed by the Case Western Reserve University Rodent Behavior Core.

Elevated plus maze. The maze consisted of two open and two closed arms crossing each other $\sim 1 \mathrm{~m}$ above the floor. The maze was fitted with infrared grid and video tracking system (Med Associates). Individual test mice were placed in the center facing the open arm, and their activity was measured for $5 \mathrm{~min}$. The total time spent in open versus closed arms, and the number of entries into each arm was scored; the number of head dips and frequency of urination/defecation were noted manually.

Open field test. A box $(40 \mathrm{~cm} \times 40 \mathrm{~cm})$ was placed in a dimly lit environment. EthoVision XT 5.0 (Noldus) was used to digitally subdivide the box area into a $20 \mathrm{~cm} \times 20 \mathrm{~cm}$ center area and a periphery. The peripheral area was further divided into middle (inner $10 \mathrm{~cm}$ ) and an outer area (outer $10 \mathrm{~cm}$ ) to determine thigmotaxic behavior. Mice were placed in the center and allowed to explore the area freely for $15 \mathrm{~min}$. Locomotor parameters, such as total distance moved, velocity, angular velocity, and heading degrees, were measured to determine basic locomotor activity and presence of stereotypies. Frequency and duration in the center, periphery, and outer quadrants were collected to determine anxiety-like behavior. In addition, data were nested into $5 \mathrm{~min}$ bins, and 
distance moved during each of these 3 periods was recorded to evaluate habituation differences across groups.

Novel object. This assay was conducted $24 \mathrm{~h}$ following the open field test in the same arena. Each subject mouse was placed in the chamber containing two identical objects and allowed free exploration for $10 \mathrm{~min}$. After the habituation period and following a $3 \mathrm{~h}$ delay, one of the familiar objects was switched to a novel object, and the test mice were returned to the same chamber in which they were habituated. The time spent sniffing each object was measured by an individual blinded to the genotypes of the tested mice. Data were normalized to the total time spent sniffing and reported as a Discrimination Index (DI). We scored the amount of time spend sniffing novel (NO) versus previously habituated object $(\mathrm{HO})$ and calculated the DI using the following formula: DI = $(\mathrm{NO}) /(\mathrm{NO}+\mathrm{HO})$. Three different cohorts of mice were evaluated in three independent experiments. Mice that did not sniff either object and/or did not sniff for a total of $4 \mathrm{~s}$ were excluded from the final analysis.

\section{Results}

The 16p11.2del mice display reduced body weight, brain weight, and cortical area

In mice lacking ERK2 or both ERK isoforms, diminished ERK activity during early cortical development results in changes in brain size due to altered progenitor proliferation and aberrant cortical cytoarchitecture (Imamura et al., 2010; Satoh et al., 2011b; Pucilowska et al., 2012). We and others have previously reported that genetic ablation of ERK2 during early brain development leads to ASD-related phenotypes (Satoh et al., 2011a; Kalkman, 2012). These findings prompted the investigation of the $16 p 11.2 \mathrm{del}$ mice. The ERK1 gene MAPK3 as well as the ERK pathway modulator MVP are located in the 16p11.2 locus; we thus hypothesized that the effects of the 16p11.2 deletion may converge on the ERK pathway and elicit developmental changes in corticogenesis and brain development that parallel those observed in the ERK2 null mice. First, we evaluated the gross brain morphology of the $16 p 11.2 \mathrm{del}$ mice. We report that these mice exhibit a modest reduction in brain size during early postnatal development, with a 7\% difference by P10, compared with wild-type (WT) littermate controls (Fig. 1a,c,c'). This change in brain weight persists in the adult mice (Fig. $1 a, c^{\prime}$ ), which is consistent with previous findings (Horev et al., 2011). In addition, we found that the $16 p 11.2 \mathrm{del}$ mice showed a significant decrease in cortical area specifically, anteroposterior length and cortical length (Fig. 1b,d) compared with WT littermate control mice at P2 and P10 (Fig. 1b,d,e). In addition, we also measured body weight of $16 p 11.2 \mathrm{del}$ mice and found a consistent $20 \%$ reduction at P2, P10, and P120 compared with WT littermate controls (Fig. 1c). It is interesting to note that cortical thickness is decreased in human carriers (Maillard et al., 2014) and mice harboring the heterozygous deletion. However, syntenic human carriers show a consistent increase in overall brain volume and weight, which is dissimilar to mouse models of the deletion that exhibit smaller brain volumes (Qureshi et al., 2014). This enig- matic discrepancy between human and mouse models requires further study.

\section{The 16p11.2del mice exhibit altered cortical cytoarchitecture and frequency of neuron generation in the early postnatal brain}

To evaluate whether $16 p 11.2 \mathrm{del}$ mice exhibit altered cellular composition of the postnatal cortex, we used IHC to quantify the number of cortical projection neurons (CPNs) using laminaspecific markers in P2 mutant and WT littermate cortices (Fig. 2). A detailed examination of the cortex of these mice revealed perturbations in cortical cytoarchitecture strikingly similar to those we previously observed in mice with ERK deletions (Pucilowska et al., 2012). Specifically, we report an overall 20\%-30\% decrease in upper layer CPNs delineated by expression of Brn1 (28\% decrease), Cux1 (nonsignificant decrease), and SatB2 (15\% decrease) (Fig. 2a,b). These projection neurons are generated mostly from SVZ progenitors during mid- and later stages of cortical neurogenesis (Tarabykin et al., 2001; Wu et al., 2005). These cells occupy cortical layers II-III and form corticocortical connections, some of which project to contralateral hemisphere across the corpus callosum (McConnell and Kaznowski, 1991). Surprisingly, we also noted an $11 \%$ increase in layer VI corticothalamic, Tbr $1^{+}$projection neurons (Fig. $2 a, b$ ). We did not, however, observe any changes in layer $\mathrm{V}, \mathrm{Ctip} 2{ }^{+}$subcortical neurons. The neurons of layer $\mathrm{V}$ and $\mathrm{VI}$ derive mostly from $\mathrm{VZ}$ progenitors during early neurogenesis (Englund et al., 2005) and 


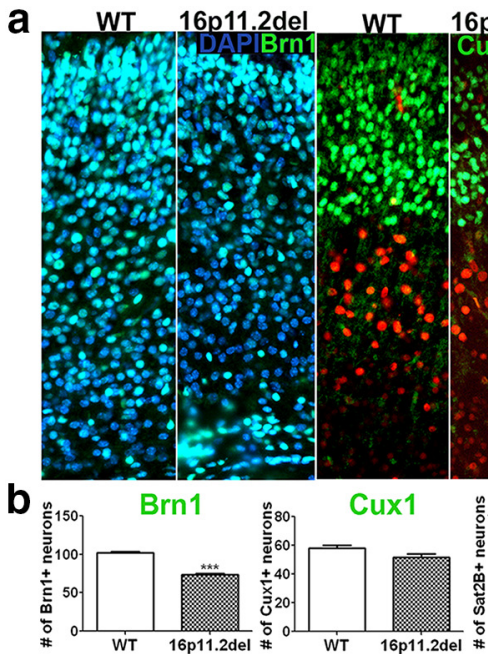

16p11.2de

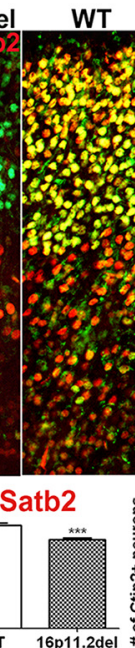

16p11.2del WT 16p11.2del

C

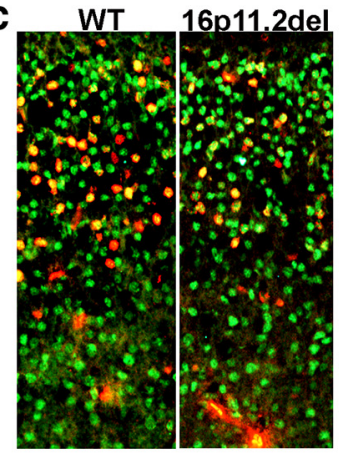

BrdU@E14.5->Brn1@P2

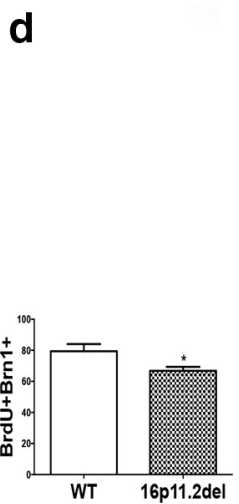

e

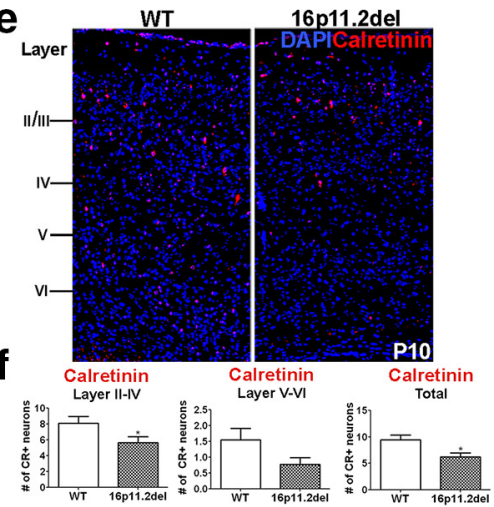

Figure 2. $16 \mathrm{p} 11.2 \mathrm{de} /$ mice show perturbations in cortical cytoarchitecture corresponding to changes in neuronal frequency in the postnatal brain. $\boldsymbol{a}$, Coronal sections of P2 brains of $16 \mathrm{p} 11.2 \mathrm{del}$ mice stained with the layers II-IV markers Brn1 (green), Cux1 (green), and Sat2B (red) compared with WT. Ctip2 (red) is a marker for layer V and Tbr1for layer VI (green). b, Layer-specific neurons were quantified at P2. 16p11.2del mice exhibit decreased neurons in the upper lamina: $B r n 1^{+}$neurons $\left({ }^{* * *} p<0.0001\right)$, Cux ${ }^{+}$neurons $(p=0.087)$, and Satb2 ${ }^{+}$neurons $\left.{ }^{* * *} p<0.0001\right)$. Conversely, 16p11.2del mice have an increased number of layer VI corticothalamic neurons (anti-Tbr1 antibody, green) $\left({ }^{*} p=0.0197\right)$. Number of layer V, Ctip2 ${ }^{+}$(red) is unchanged ( $p=$ $0.84)\left(n_{\text {del }}=11 ; n_{w t}=10\right) . \boldsymbol{c}, \boldsymbol{d}$, The frequency of neuronal birth atE14.5 is altered in 16p11.2de/ mice. A single BrdU injection was administered to plug checked pregnant dams at E14.5. The frequency of neurons generated at E14.5 was examined at P2 by counting the number of BrdU ${ }^{+}$cells (red) that expressed the marker of upper cortical projection neurons (Brn1 ${ }^{+}$, green). $\boldsymbol{d}$, The $16 p 11.2$ del mice showed a decrease in the frequency of neuronal birth ( $\left.{ }^{*} p=0.0412\right)$ (ndel $\left.=6 ; n w t=7\right) \cdot e$, Coronal sections of P10 brains stained for the calretinin-positive intereneurons. $f$, Calretinin ${ }^{+}$interneurons in the upper layers, deeper layers, and total were quantified. 16p11.2de/ mice show a decrease in calretinin ${ }^{+}$interneurons in upper layers $\left({ }^{*} p=0.026\right)$ and in total cortex $\left({ }^{*} p=0.012\right)$, whereas deeper layers showed a nonsignificant decrease $(p=0.13)\left(\mathrm{n}_{\mathrm{del}}=3 ; \mathrm{n}_{\mathrm{wt}}=3\right)$. ${ }^{*} p<0.05 .{ }^{* * *} p<0.0001$.

project to subcortical targets, including the thalamus, midbrain, pons, and spinal cord. It is interesting to note that, whereas the phenotype of late born, upper CPNs in the 16p11.2del mice mimics the deficits observed in the ERK knock-out mice, the earlier born subcortical neurons show an opposite phenotype, compared with the ERK2 null mice, because in the ERK2 KOs the number of layer V neurons is increased, whereas in the 16p11.2 del mice it is layer VI neurons that are increased. This is most likely due to conditional versus germline ERK inactivation affecting neurogenesis. In addition, we also observed a $30 \%$ decrease in calretinin-positive interneurons in 16p11.2del mice compared with WT controls, with upper layers exhibiting larger deficits than deeper layers of the cortex (Fig. 2e,f).

We previously reported that the postnatal changes in cortical cytoarchitecture observed in the ERK deletion mice are due to altered progenitor proliferation during cortical neurogenesis. Therefore, we tested whether the frequency of neurons born at
E14.5 was altered in the $16 p 11.2 \mathrm{del}$ mice as reflected by the number of $\mathrm{BrdU}^{+} / \mathrm{Brn}^{+}$ neurons at P2. We observed a $20 \%$ decrease in the number of Brn $1^{+}$neurons born during mid-neurogenesis in 16p11.2del mice compared with WT controls (Fig. $2 c, d$ ). We did not note any differences in apoptosis (data not shown). Therefore, we concluded that the deficits in superficial cortical projections are linked to perturbations in cortical neurogenesis.

Frequency of apical and basal mitotic progenitors is increased in $16 p 11.2 \mathrm{del}$ mice during mid-neurogenesis

To establish whether the perturbations in cortical cytoarchitecture observed in the $16 p 11.2 \mathrm{del}$ mice are due to altered progenitor proliferation dynamics during cortical neurogenesis, we examined both apical progenitor, which include neuroepithelial and radial glial cells, and basal progenitor mitoses (Gaiano et al., 2000; Malatesta et al., 2000; Noctor et al., 2001). We have previously established an ERK-dependent mechanism, which links aberrant proliferation of neuronal progenitors and altered cell cycle kinetics at the VZ to abnormalities in postnatal brain cytoarchitecture (Pucilowska et al., 2012). Using the mitotic marker $\mathrm{PH} 3$, we detected a significant increase in the number of proliferating progenitors at early and midneurogenesis (E12.5 and E14.5) in the 16p11.2del mice compared with WT littermate controls (Fig. 3a,b). Specifically, the number of nonventricular mitoses of intermediate progenitor cells (IPCs) located basally in the SVZ was increased by $35 \%$ in the $16 p 11.2$ del (Fig. $3 a, b$ ) compared with WT. We observed a trend toward an increase in the number of mitotic progenitors in the VZ, which harbors apical progenitors generating mostly deeper subcortical PNs. These changes were more pronounced in the rostral VZ. However, in the ganglionic eminences of the ventral forebrain, the number of mitosis was comparable between 16p11.2del and WT mice. To determine whether the increase in apical and basal mitosis corresponded to an increase in the number of mitotic radial glia and basal IPCs and not another cell type, we used IHC to colabel mitotic cells with a marker exclusively delineating the identity of these cells during mid-neurogenesis. We used the T-domain transcription factor Tbr2 to identify IPCs residing in the SVZ (Englund et al., 2005). We report that the number of mitotic IPCs ( $\mathrm{PH}^{+} / \mathrm{Tbr}^{+}$) was increased by $37 \%$ (Fig. 3c,d), consistent with the number of basal mitosis in the SVZ. We conclude that, in the $16 p 11.2 \mathrm{del}$ mice, the increase in frequency of basal $\mathrm{PH} 3{ }^{+}$mitosis represents an increase in mitotic IPCs specifically. Additionally, we also noted a corresponding increase in newly postmitotic, Tbr1 ${ }^{+}$neurons (data not shown). Because most IPCs are able to undergo only one or possibly two progenitor divisions during corticogenesis (Haubensak et al., 2004; 
Kawaguchi et al., 2004; Noctor et al., 2004), the newly born postmitotic Tbr ${ }^{+}$ neurons most likely arise as a consequence of these extra mitoses. Overall, these data indicate that the aberrant changes in proliferation of apical and basal progenitors during early cortical neurogenesis in the $16 p 11.2$ del mice result in the generation of abnormal numbers of postmitotic cortical projection neurons.

Generation and number of Tbr $2^{+}$IPCs are decreased in the $16 p 11.2 \mathrm{del}$ mice In mammals, during cortical development, there is a distinct spatial and temporal sequence of progenitor divisions in which $\mathrm{Pax}^{+}$neuroepithelial and radial glial cells generate all of the Tbr ${ }^{+}$IPCs and/or postmitotic neurons, oligodendrocytes, and astrocytes. Changes in apical progenitor proliferation dynamics in the nascent cortex of $16 p 11.2 \mathrm{del}$ mice led us to further investigate whether the number and generation of IPCs may be altered as well. Therefore, we counted the number of progenitor cells coexpressing Pax6 and Tbr2 in the 16p11.2del mice and WT, littermate controls at E14.5. We observed that the number of doubly labeled progenitors is reduced by $40 \%$ (Fig. $4 a, b, e$ ), suggesting that $\mathrm{Pax}^{+}{ }^{+}$radial glia, which harbor only one copy of the ERK1 isoform, do not appropriately differentiate into Tbr ${ }^{+}$IPCs and therefore impede their generation. We also noticed that this decrease in double-positive cells was present in the lateral as well as in dorsomedial portions of the developing cortex. Because the number of transitioning $\mathrm{Pax} 6^{+} / \mathrm{Tbr} 2^{+}$progenitors was reduced, we hypothesized that the number of IPCs generated from $\mathrm{Pax} 6^{+}$apical progenitors may be altered. Consequently, we found that the number of Tbr ${ }^{+}$IPCs in the cortical proliferation zones (VZ and SVZ) was reduced by nearly $20 \%$ in the $16 p 11.2 \mathrm{del}$ mice (Fig. $4 a, b, d$ ). In addition, there is a reduction in the number of $\mathrm{Pax}^{+}{ }^{+}$progenitors in the $\mathrm{VZ}$ at E14.5, most likely due to differentiation into Tbr $1^{+}$postmitotic neurons. The most parsimonious explanation for these findings is that, during cortical development, the frequency of generation and the number of Tbr $2^{+}$intermediate progenitor cells are compromised, leading to premature progenitor pool depletion. Alternatively, it is possible that the acceleration in the cell cycle could lead to fewer IPCs. Both of these mechanisms could account for the observed deficits in upper cortical lamina in adult 16p11.2del mice.

16p11.2del mice exhibit premature cell cycle exit during midneurogenesis

We previously reported that altered progenitor generation in the ERK2 deletion mice is a consequence of premature progenitor cell cycle withdrawal, resulting in diminished progenitor pools during neurogenesis (Pucilowska et al., 2012). Because we observe an analogous decrease in apical and basal progenitor pools in the 16p11.2del mice (Fig. 4a-e), we evaluated the deletion mice for premature cell cycle withdrawal. To quantitatively compare the fraction of proliferating cells leaving the cell cycle, we colabeled $\mathrm{BrdU}^{+}$cells ( $24 \mathrm{~h}$ following a single BrdU injection) with a mitotic marker, Ki67. The number of $\mathrm{BrdU}^{+}$but $\mathrm{Ki}^{-} 7^{-}$progenitors was counted in a $100 \mu \mathrm{m}$ areas of dorsomedial and dorsolateral telencephalon and divided over the total number of $\mathrm{BrdU}^{+}$, cycling cells. We determined the percentage of cells exiting the cell cycle (calculated based on a total number of cycling cells) was increased by $30 \%$ in the $16 p 11.2 \mathrm{del}$ mice compared with WT, littermate controls (Fig $4 f, g$ ). These results demonstrate that more cells are leaving the cell cycle during mid-neurogenesis, altering the number of progenitors that contribute to the cortical lamina deficits we observe in the $16 p 11.2 \mathrm{del}$ mice.

\section{ERK activity and protein levels are altered in the 16p11.2del mice}

We previously established that ERKs are necessary for normal progenitor proliferation during cortical neurogenesis and that loss of ERK activity led to a decrease in progenitor proliferation, altering cell cycle dynamics in the VZ (Pucilowska et al., 2012). Because ERK1 is included in the deleted interval of the 16p11.2del mice, we evaluated the expression and activity of ERK1 and ERK2 in the cortex and hippocampus of the 16p11.2del mice. PhosphoERK1/2 expression in the forebrain is primarily present in the VZ and, remarkably, appears elevated in the $16 p 11.2 \mathrm{del}$ mice using 

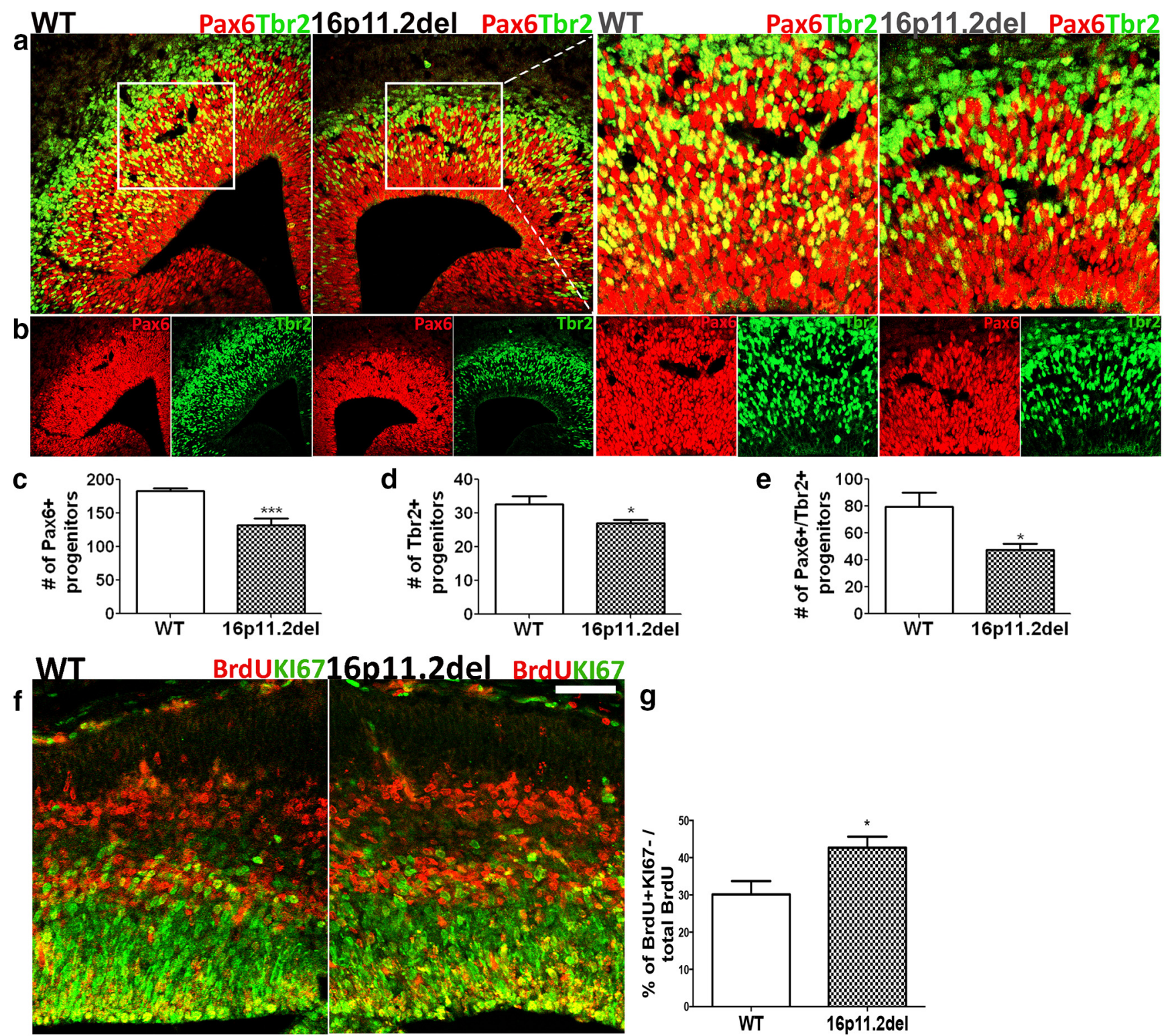

Figure 4. 16p11.2de/ mice exhibit changes in basal progenitor number and generation, resulting in premature progenitor pool depletion and early cell cycle exit. $\boldsymbol{a}, \boldsymbol{b}$, AtE14.5, the number of IPCs and apical progenitors were analyzed by IHC with anti-Tbr2 (green) and anti-Pax6 (red), respectively. IPC generation from apical progenitors was assessed by counting colabeled Tbr2 ${ }^{+}$cells (green) and $\mathrm{Pax}^{+}{ }^{+}$(red) radial glial cells, identifying progenitors transitioning to an IPC fate (yellow).c, Pax6 ${ }^{+}$progenitors, Tbr2 ${ }^{+}$progenitors, and colabeled cells were quantified. 16p 11.2 del mice show a decrease in the number of Pax6 ${ }^{+}$cells $\left({ }^{* * *} p=0.001\right)$, Tbr $^{+}{ }^{+} \mathrm{IPC}\left({ }^{*} p=0.049\right)$, and colabeled Pax6 ${ }^{+} / \mathrm{Tbr} 2^{+}$cells $\left({ }^{*} p=0.0276\right) . \mathrm{n}_{\text {del }}=5-7 ; \mathrm{n}_{\mathrm{wt}}=5-7 . \boldsymbol{d}, \boldsymbol{e}, \mathrm{IHC}$ with a mitotic marker Ki67 (green) and BrdU (red) antibodies after a single BrdU intraperitoneal injection at E13.5. The leaving fraction comprised of all cells that exited the cell cycle within a $24 \mathrm{~h}$ period after the BrdU pulse; therefore, $\mathrm{BrdU}^{+} / \mathrm{Ki}_{67}{ }^{-}$were counted (red) and then presented as a percentage of all BrdU ${ }^{+}$proliferating cells.f, $\boldsymbol{g}$, The $16 \mathrm{p} 11.2$ del mice show a premature cell cycle exit compared with littermate controls at E14.5 quantified by the number of cells that exited the cell cycle $(* * p=0.0015)\left(\mathrm{n}_{\mathrm{wt}}=6 ; \mathrm{n}_{\text {del }}=5\right)$ and percentage of cells that exited the cell cycle $\left({ }^{*} p=0.0282\right) ;\left(\mathrm{n}_{\mathrm{wt}}=6 ; \mathrm{n}_{\text {del }}=\right.$ 5). All data analysis was conducted blinded to the genotype of all mice. ${ }^{*} p<0.05 .{ }^{* * *} p<0.001$. Scale bar: $f, 50 \mu \mathrm{m}$.

IHC (Fig. 5a). To quantify this increase, we isolated cortical lysates of WT and 16p11.2del littermate embryos at midneurogenesis (E14.5) for Western blots. We observed a decrease in total ERK1 protein levels, consistent with the loss of one Mapk3 allele in the 16p11.2del mice, and unchanged levels of ERK2 protein (Fig. 5b,c). Consistent with the IHC results, we found a paradoxical increase in the phosphorylated, activated forms of ERK1, ERK2, and combined ERK1/2, compared with total ERK protein levels in the 16p11.2del cortex and hippocampus (Fig. 5a,b). These data demonstrate that mice hemizygous for $16 \mathrm{p} 11.2$ deletion exhibit aberrant upregulation of ERK activity.
Levels of $\mathrm{p} 27^{\mathrm{Kip} 1}$ and cyclin D1 are altered in 16p11.2del mouse model at mid-neurogenesis

In an effort to establish the mechanisms involved in the altered corticogenesis in the 16p11.2 del mice, we examined the cell cycle regulators $\mathrm{p} 27^{\mathrm{Kip} 1}$ and cyclin D1 (Fig. 6). We and others have previously established that these potent cell cycle regulators are direct targets of ERK signaling and play important roles in progenitor proliferation (Calegari and Huttner, 2003; Dehay and Kennedy, 2007; Lange et al., 2009; Pucilowska et al., 2012). In the cytoplasm, p2 $7^{\mathrm{Kip} 1}$ is phosphorylated by the ERKs, which promotes its proteolytic degradation, thus allowing cell cycle progression. Cyclin D1 is transcriptionally regulated by the ERKs, 

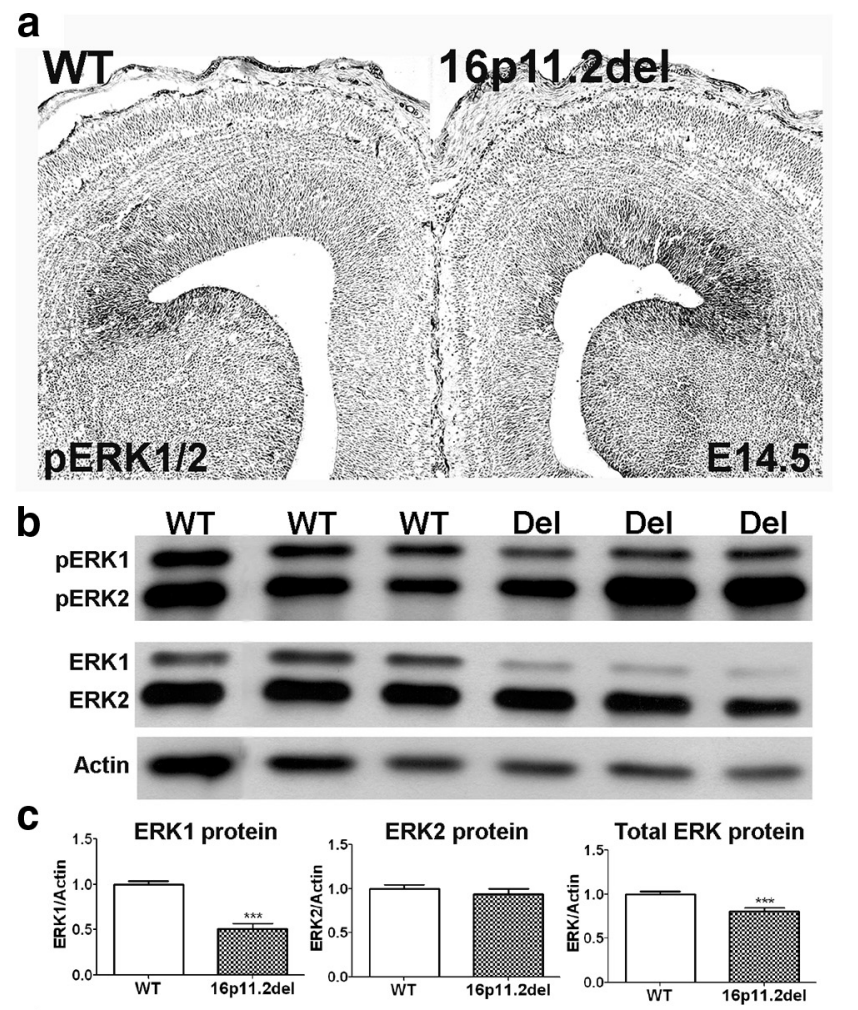

d

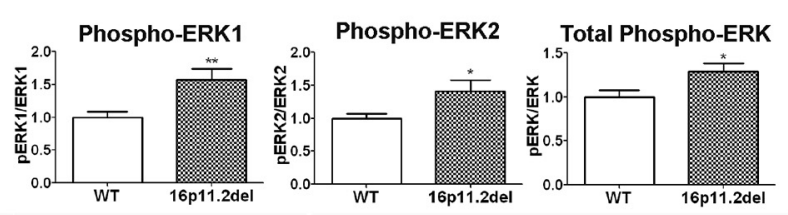

Figure 5. ERK activity and protein levels are altered in the $16 p 11.2$ de/ cortex. $\boldsymbol{a}$, IHC of phospho-ERK1/2 from E14.5 WT and 16p11.2del forebrains. ERK activity primarily localizes to ventricular zones and is increased in $16 p 11.2 \mathrm{de} /$ mice. $\boldsymbol{b}$, Western blot analysis of cortical lysates isolated from E14.5 embryos of WT and 16p11.2del (Del) littermates. c, $16 p 11.2$ del mice have decreased levels of ERK1 $\left({ }^{* *} p<0.001\right)$ and combined ERK1/2 $\left({ }^{* *} p=0.0007\right)$, but normal ERK2 levels $(p=0.43)$ due to loss of one ERK1 allele. $\boldsymbol{d}$, $16 p 11.2 \mathrm{del}$ mice have increased levels of phosphorylated ERK1 ( $\left.{ }^{* *} p=0.0051\right)$, ERK2 $\left({ }^{*} p=0.0255\right)$, and combined phospho-ERK1/2 $\left({ }^{*} p=0.02, \mathrm{n}_{\mathrm{wt}}=17\right.$ and $\left.\mathrm{n}_{\mathrm{del}}=16\right)$. ${ }^{*} p<0.05$. ${ }^{* *} p<0.01$. ${ }^{* * *} p<0.001$.

expressed in proliferative zones of the developing cortex and acts to regulate the $G_{1} / S$ cell cycle transition and thus the length of $\mathrm{G}_{1}$ (Lukas et al., 1996; Glickstein et al., 2009). Therefore, we prepared E14.5 cortical lysates and used Western blotting and IHC to evaluate changes in their expressions levels in $16 p 11.2 \mathrm{del}$ cortices and WT, littermate controls. We observed a significant $35 \%$ decrease in $\mathrm{p} 27^{\mathrm{kip} 1}$ by Western analysis as well as IHC (Fig. $6 a-c$ ). We also used Western blotting and IHC to establish that the levels of cyclin D1 are significantly elevated in the 16p11.2 del mice and are most likely a consequence of enhanced ERK signaling in the proliferative zones of the cortex (Fig. $6 d-f$ ).

\section{6p11.2del adult mice exhibit anxiety-like behavior and hyperactivity}

We questioned whether changes in corticogenesis and ERK activity in the $16 p 11.2 \mathrm{del}$ mice contribute to behavioral deficits in the 16p11.2del mice. Because telencephalic ERK2 knock-outs exhibit a strong anxiety-like phenotype (Pucilowska et al., 2012), we evaluated 3-month-old 16p11.2 del male mice using the elevated plus maze test (Fig. 7a). We found that the 16p11.2del mice spent less time exploring the open arms of the maze compared with WT, age-matched controls. We calculated the total percentage of time spent in the open arms and total open entrances (Fig. 7a) and report significant deficits in both, which is reflective of anxiety-like behavior. We did not observe significant changes in the total number of explorations between the genotypes (Fig. 7a). Because the 16p11.2del mice show anxiety-like behavior, we evaluated them in an open field test and observed a significant decrease in the frequency the deletion mice entered the center, middle, and outer parameter of the open field chamber during the first $5 \mathrm{~min}$ of exploration (Fig. 7b). Additionally, we also noted a complementary $35 \%$ decrease in the total distance traveled within the first $5 \mathrm{~min}$ of the test (Fig. $7 b$ ). These effects were not due to generalized hypoactivity as we did not observe any differences in WT and 16p11.2del mice when these parameters were evaluated over the last 5 min of the test (Fig. $7 b$ ). Therefore, we suggest an anxiety-like basis for this behavior. Next, we evaluated memory using a novel object recognition task. Based on the calculated DI, where 0.5 indicates no object preference, we found that the $16 p 11.2 \mathrm{del}$ mice were impaired in their ability to discriminate between novel and familiar objects, which is reflective of recognition memory deficits (Fig. 7c). Importantly, the exploration time during the habituation phase of the test was not different between the 16p11.2del and WT mice, which excludes limited object exploration as a reason for a lack of object preference (Fig. 7c). The behavioral analyses suggest that $16 p 11.2 \mathrm{del}$ mice exhibit anxiety-like behavior and memory deficits similar to phenotypes observed in the ERK1 and ERK2 null mice.

\section{Discussion}

Developmental defects arising from aberrant brain patterning, cytoarchitecture, and circuitry are associated with intellectual disabilities, including ASDs (Ross and Walsh, 2001). Cortical complexity and brain size in higher mammals are developmentally linked to the generation of progenitors in the SVZ (Kriegstein et al., 2006; Martínez-Cerdeño et al., 2006). Perturbations in neural progenitor proliferation affect the timing and generation of cortical projection neurons, resulting in aberrant circuitry and connectivity. Indeed, abnormalities associated with aberrant numbers of upper layer CPNs are associated with defects in abstract reasoning, problem solving, and generalization (Paul et al., 2007) and have been reported in ASD patients (Minshew and Williams, 2007; Freitag et al., 2009). The new murine model of chromosomal deletion syntenic to human 16p11.2 allows for investigation of the CNS defects associated with this deletion. The dynamics of cortical neurogenesis have not been studied in the $16 p 11.2 \mathrm{del}$ mouse despite established changes in cortical thickness in human patients. We report altered cortical neurogenesis in the $16 p 11.2 \mathrm{del}$ mouse that results in aberrant cortical circuitry and brain function that is associated with dysregulation of ERK signaling.

We and others have previously documented that the ERK MAP kinases are important for normal cortical development and function and are genetically linked to intellectual disabilities, including disorders of cognition and CNVs (Samuels et al., 2008, 2009; Imamura et al., 2010; Satoh et al., 2011b; Kalkman, 2012; Pucilowska et al., 2012). The ERK2 conditional knock-outs show perturbations in neurogenesis resulting in aberrant cortical cytoarchitecture, physiology, and behavior (Satoh et al., 2011a; Pucilowska et al., 2012). We report that the 16p11.2del mouse 


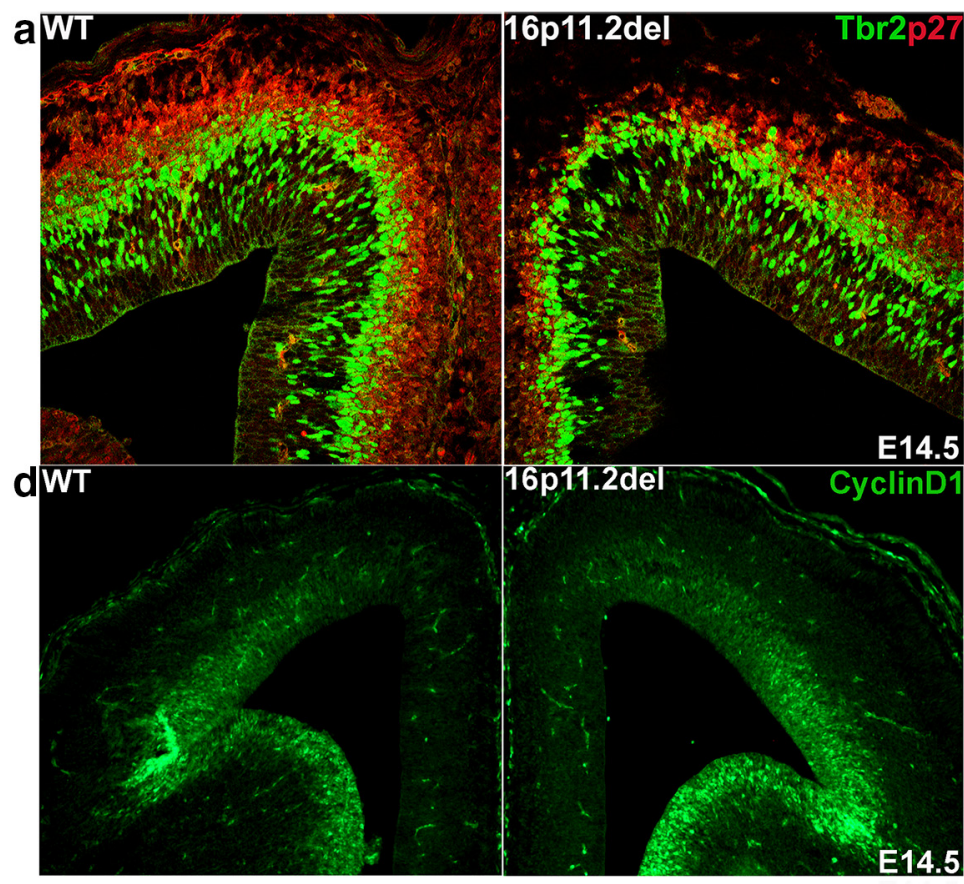

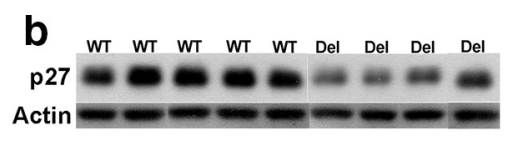
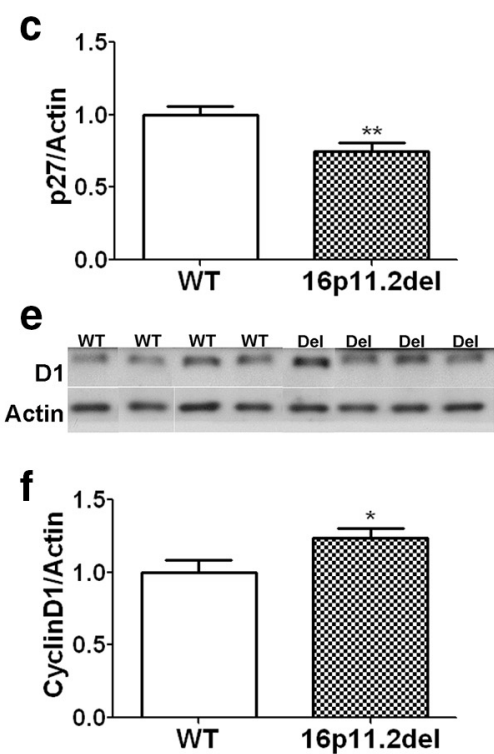

Figure 6. Hyperactivation of the ERK pathway in the 16p11.2del mice alters expression of key cell cycle regulators, cyclin D1 and p27 Kip1, in the developing cortex. $\boldsymbol{a}$, Expression of p27 ${ }^{\text {Kip } 1}$ (red) was evaluated in the developing cortex at E14.5 and in intermediate progenitors marked by Tbr2 (green). $\boldsymbol{b}$, Western blot of p27 ${ }^{\text {Kip } 1}$ and actin loading control from E14.5 WT and $16 p 11.2 \mathrm{del}$ (Del) cortical lysates. c, Quantification of $\mathrm{p} 27^{\mathrm{Kip} 1}$ from Western blots shows reduced levels in $16 \mathrm{p} 11.2 \mathrm{de} / \mathrm{mice}$ compared with WT at E14.5 $\left({ }^{* *} p=0.0062, \mathrm{n}_{\text {wt }}=14\right.$, $\mathrm{n}_{\mathrm{del}}=12$ ).d, Cyclin D1 (red) expression in E14.5 cortices from WT and 16p11.2de/ mice was evaluated.e, Western blot of cyclin D1 and actin control from E14.5 WT and 16p11.2del (Del) cortical lysates are quantified in $\boldsymbol{f}$. $\boldsymbol{f}, 16 p 11.2$ del mice exhibit increased cyclinD1 levels compared with WT $\left({ }^{*} p=0.0428, \mathrm{n}_{\text {wt }}=8, \mathrm{n}_{\text {del }}=8\right) .{ }^{*} p<0.05$. ${ }^{* *} p<0.01$.

exhibits analogous deficits, including reduction in brain size, which is consistent with previous findings (Horev et al., 2011). The 16p11.2del mice also show an increase in progenitor proliferation during early and mid-neurogenesis (E12.5 and E14.5) in both the VZ and SVZ, as evidenced by increased number of $\mathrm{PH} 3{ }^{+}$mitotic cells. This change was coincident with a reduced number of $\mathrm{Pax}^{+}{ }^{+}$radial glia and Tbr $2^{+}$IPCs, as well as the number of $\mathrm{Pax} 6{ }^{+} / \mathrm{Tbr} 2^{+}$transitioning progenitors. The increase in progenitor proliferation is postulated to arise from ERKdependent proliferation of early progenitor pools, ultimately resulting in their accelerated depletion and a significantly increased leaving fraction. Consequently, the accelerated cell cycle exit results in aberrant increase in layer VI corticothalamic projections in the mature brain, depleting the number of Tbr $2^{+}$IPCs, ultimately resulting in reduced number of CPNs in layers II/III. The decrease in layer II/III also extends to calretinin-positive inhibitory interneurons. Previous work has shown that SatB2 ${ }^{+} \mathrm{CPNs}$ express chemotactic cues that promote migration of interneurons into the upper cortical lamina (Lodato et al., 2011). Thus, deficits in layer II/III CPNs will ultimately result in decreased recruitment of calretinin interneurons. Migration deficits represent an alternate mechanism for the cytoarchitectural changes, but we did not observe any aberrantly positioned neurons and therefore do not attribute these changes to migration deficits.

The cortical phenotype of decreased upper-layer and increased deeper-layer neurons in the 16p11.2del mice parallels that observed in ERK knock-out mice. An important finding in this study is that we observe similar cortical defects that can arise from both an overall increase in ERK activity in the 16p11.2 mice and reduced ERK activity in knock-out mice. Thus, normal cortical development requires ERK activity maintained within a narrow dynamic range. The 16p11.2del mice show an increase in ERK signaling that we predicted would induce more mitotic activity and premature cell cycle exit, resulting in depletion of progenitor pools, which we experimentally confirmed. In addition, increased mitosis may be due to acceleration of the cell cycle during neurogenesis. This is consistent with the finding that $16 p 11.2 \mathrm{del}$ mice also exhibit altered levels of the cell cycle regulator p $27^{\mathrm{KIP} 1}$ and cyclin D1, which are direct targets of the ERKs and mediate their effects on progenitor proliferation. We report a significant reduction in p27 ${ }^{\text {Kip1 }}$ (Fig. 6) due to increased ERK activity resulting in its phosphorylation-stimulated degradation (Sherr and Roberts, 1999). In addition, cyclin D1 levels were higher in the cortex of the mutant mice, a result of its ERK-induced expression (Glickstein et al., 2007). Whereas overall reduction in ERK activity in ERK2 knock-out mice results in a decrease in the mitotic index and elongated cell cycle, favoring neurogenic divisions and precocious depletion of neural progenitor pools (Pucilowska et al., 2012). Thus, the common changes in cortical cytoarchitecture in the 16p11.2del and ERK knock-out mice may arise from the premature loss of dividing progenitors, an effect that we postulate is influenced by both the ERK-dependent acceleration of the cell cycle resulting initially in more neurogenic divisions, premature depletion of progenitor pools, ultimately leading to a loss of upper cortical projections. Although the exact mechanism by which increased ERK activity in the 16p11.2del mice and decreased ERK activity in the ERK2 knock-out mice results in precocious neurogenesis is unclear, these findings are not without precedent. Loss of Sprouty1 and Sprouty2, negative regulators of the MAPK pathway results in increased ERK activity coincident with an increase in the mitotic index and premature neurogenesis due to cell-cycle exit of progenitors (Faedo et al., 2010). Increasing ERK activity likely accelerates neurogenesis and maturation of radial glia by 
increasing both proliferation and differentiation of progenitors, whereas loss of ERK signaling causes cell cycle elongation resulting in progenitors favoring differentiating divisions over proliferative divisions. Furthermore, increased ERK signaling may be just one among multiple contributing factors to altered neurogenesis in the $16 p 11.2 \mathrm{del}$ mice. Although the current study cannot draw a causal relationship between altered ERK signaling and the cortical phenotype, it likely is a contributing factor given the role of ERK signaling during cortical development.

An important and paradoxical outcome of this study was the observation that the levels of phosphorylated, active forms of the ERKs were significantly increased in the 16p11.2del cortex and hippocampus at mid-neurogenesis. Given that the $16 p 11.2 \mathrm{del}$ mice are missing only one ERK1 allele, elevated ERK activity is paradoxical, but not without precedent. Indeed, we have reported that the knockout of ERK1 results in elevated ERK2 activity and conversely conditional inactivation of ERK2 in the cortex results in enhanced ERK1 activation (Nekrasova et al., 2005; Samuels et al., 2008). Brambilla and colleagues suggested that ERK1 acts as a "cell intrinsic partial agonist" and thus contributes to the precise regulation of ERK2 signaling (Indrigo et al., 2010). The most direct explanation is that loss of one copy of ERK1 allele reduces its protein levels, thus reducing substrate competition for its upstream regulator MEK, ultimately resulting in increased ERK1/2 activity. However, because of the magnitude of increased ERK activation, this explanation seems unlikely. The ERKs are subject to complex regulation, reflective of the activity of upstream elements in the pathway, their subcellular distribution, interaction with multiple scaffolds, and extensive feedback mechanisms (Pouysségur et al., 2002; Roskoski, 2012). The 16p11.2 locus contains 27 genes, including the MVP gene, which is postulated to act as an ERK scaffold and may contribute to regulation of the ERK signaling pathway (Kolli, 2004; Liang et al., 2010). Thus, it is presently unclear how ERK activity is regulated in the $16 p 11.2$ del mice; however, it is likely that the functions of other genes in the 16p11.2 locus converge on the ERK/MAPK pathway to regulate its activity.

We have previously found that decreases in layer II/III neurons result in dysregulation of network circuitry, in particular recurrent connections (Pucilowska et al., 2012). Thus, altered cortical cytoarchitecture impairs proper network formation and potentially contributes to cognitive impairment. Our analysis of the $16 p 11.2 \mathrm{del}$ mice correlates the impaired cortical development leading to a behavioral phenotype. We observed that the 16p11.2del mice exhibit anxiety-like behavior and deficits in memory, a phenotype we previously associated with the ERK2 conditional knock-out mice, suggesting that deficits in upper cortical cytoarchitecture may generate similar behavioral changes as
Elevated Plus Maze

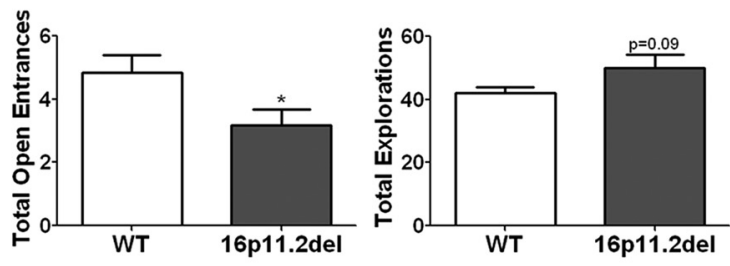

Open Field
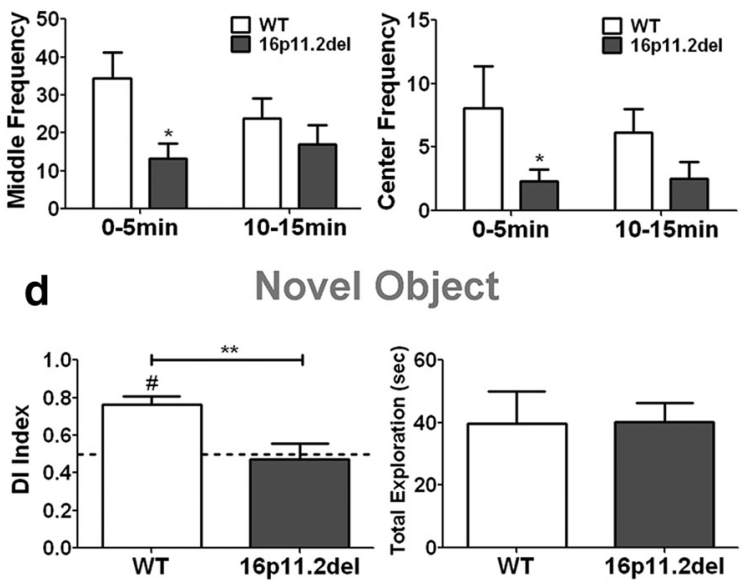

Figure 7. 16p11.2de/mice exhibit anxiety-like behavior and impaired object recognition. $\boldsymbol{a}$, Elevated plus maze: compared with mice made fewer entrances into the outer $\left({ }^{*} p=0.0404\right)$, middle $\left({ }^{*} p=0.0144\right)$, and center $\left({ }^{*} p=0.0084\right)$ zones of the chamber with a DI of 0.5 , indicative of no preference, WT mice showed significant preference for the novel object ( $\left.{ }^{\#} p=0.0002\right)$, whereas W.0051). 16p11.2del showed no difference in object investigation during the habituation phase $(p=$

well and recapitulate some of the endotypes of the human disorder. Mills and colleagues (Horev et al., 2011) have previously reported that the $16 p 11.2 \mathrm{del}$ mice exhibit motor stereotypes, changes in diurnal rhythm, and increased hyperactivity but did not detect altered social behaviors. Furthermore, work by Portman et al. (2014) shows that a slightly different mouse model of the 16p11.2 deletion exhibits sporadic stereotypies, memory impairments, but not anxiety or social interaction deficits. These behavioral differences may be a consequence of different deletion intervals and genetic backgrounds. Additionally, patients with 16p11.2 CNVs present with highly heterogeneous symptoms, suggesting that the behavioral phenotypes in mice may be highly variable as well.

Aberrant activity in the ERK pathway has been recently linked to several developmental disorders, including autism (Schubbert et al., 2007; Levitt and Campbell, 2009; Samuels et al., 2009). Genetic evidence from mutations in elements of the ERK cascade illustrates a clear association between cognitive function and altered ERK activity. An enigmatic and unexplained finding is that both loss- and gain-of-function mutations in elements of the ERK pathway yield similar clinical phenotypes. The findings in this study reinforce the prevailing view that there is a physiological requirement for very specific and dynamic regulation of ERK activity during cortical neurogenesis, where activity outside of normal range perturbs normal cortical development. 


\section{References}

Adams JP, Sweatt JD (2002) Molecular psychology: roles for the ERK MAP kinase cascade in memory. Annu Rev Pharmacol Toxicol 42:135-163. CrossRef Medline

Calegari F, Huttner WB (2003) An inhibition of cyclin-dependent kinases that lengthens, but does not arrest, neuroepithelial cell cycle induces premature neurogenesis. J Cell Sci 116:4947-4955. CrossRef Medline

Courchesne E, Pierce K, Schumann CM, Redcay E, Buckwalter JA, Kennedy DP, Morgan J (2007) Mapping early brain development in autism. Neuron 56:399-413. CrossRef Medline

Dehay C, Kennedy H (2007) Cell-cycle control and cortical development. Nat Rev Neurosci 8:438-450. CrossRef Medline

Englund C, Fink A, Lau C, Pham D, Daza RA, Bulfone A, Kowalczyk T, Hevner RF (2005) Pax6, Tbr2, and Tbr1 are expressed sequentially by radial glia, intermediate progenitor cells, and postmitotic neurons in developing neocortex. J Neurosci 25:247-251. CrossRef Medline

Faedo A, Borello U, Rubenstein JL (2010) Repression of Fgf signaling by sprouty $1-2$ regulates cortical patterning in two distinct regions and times. J Neurosci 30:4015-4023. CrossRef Medline

Fernandez BA, Roberts W, Chung B, Weksberg R, Meyn S, Szatmari P, Joseph-George AM, Mackay S, Whitten K, Noble B, Vardy C, Crosbie V, Luscombe S, Tucker E, Turner L, Marshall CR, Scherer SW (2010) Phenotypic spectrum associated with de novo and inherited deletions and duplications at 16p11.2 in individuals ascertained for diagnosis of autism spectrum disorder. J Med Genet 47:195-203. CrossRef Medline

Freitag CM, Luders E, Hulst HE, Narr KL, Thompson PM, Toga AW, Krick C, Konrad C (2009) Total brain volume and corpus callosum size in medication-naïve adolescents and young adults with autism spectrum disorder. Biol Psychiatry 66:316-319. CrossRef Medline

Gaiano N, Nye JS, Fishell G (2000) Radial glial identity is promoted by Notch1 signaling in the murine forebrain. Neuron 26:395-404. CrossRef Medline

Glickstein SB, Alexander S, Ross ME (2007) Differences in cyclin D2 and D1 protein expression distinguish forebrain progenitor subsets. Cereb Cortex 17:632-642. CrossRef Medline

Glickstein SB, Monaghan JA, Koeller HB, Jones TK, Ross ME (2009) Cyclin D2 is critical for intermediate progenitor cell proliferation in the embryonic cortex. J Neurosci 29:9614-9624. CrossRef Medline

Haubensak W, Attardo A, Denk W, Huttner WB (2004) Neurons arise in the basal neuroepithelium of the early mammalian telencephalon: a major site of neurogenesis. Proc Natl Acad Sci U S A 101:3196-3201. CrossRef Medline

Horev G, Ellegood J, Lerch JP, Son YE, Muthuswamy L, Vogel H, Krieger AM, Buja A, Henkelman RM, Wigler M, Mills AA (2011) Dosage-dependent phenotypes in models of 16p11.2 lesions found in autism. Proc Natl Acad Sci U S A 108:17076-17081. CrossRef Medline

Imamura O, Pagès G, Pouysségur J, Endo S, Takishima K (2010) ERK1 and ERK2 are required for radial glial maintenance and cortical lamination. Genes Cells 15:1072-1088. CrossRef Medline

Indrigo M, Papale A, Orellana D, Brambilla R (2010) Lentiviral vectors to study the differential function of ERK1 and ERK2 MAP kinases. Methods Mol Biol 661:205-220. CrossRef Medline

Kalkman HO (2012) Potential opposite roles of the extracellular signalregulated kinase (ERK) pathway in autism spectrum and bipolar disorders. Neurosci Biobehav Rev 36:2206-2213. CrossRef Medline

Kawaguchi A, Ogawa M, Saito K, Matsuzaki F, Okano H, Miyata T (2004) Differential expression of Pax6 and Ngn2 between pair-generated cortical neurons. J Neurosci Res 78:784-795. CrossRef Medline

Kolli S, Zito CI, Mossink MH, Wiemer EA, Bennett AM (2004) The major vault protein is a novel substrate for the tyrosine phosphatase SHP-2 and scaffold protein in epidermal growth factor signaling. J Biol Chem 279: 29374-29385. CrossRef Medline

Kriegstein A, Noctor S, Martínez-Cerdeño V (2006) Patterns of neural stem and progenitor cell division may underlie evolutionary cortical expansion. Nat Rev Neurosci 7:883-890. CrossRef Medline

Kumar RA, KaraMohamed S, Sudi J, Conrad DF, Brune C, Badner JA, Gilliam TC, Nowak NJ, Cook EH Jr, Dobyns WB, Christian SL (2008) Recurrent 16p11.2 microdeletions in autism. Hum Mol Genet 17:628-638. CrossRef Medline

Lange C, Huttner WB, Calegari F (2009) Cdk4/CyclinD1 overexpression in neural stem cells shortens $G_{1}$, delays neurogenesis, and promotes the generation and expansion of basal progenitors. Cell Stem Cell 5:320-331. CrossRef Medline

Levitt P, Campbell DB (2009) The genetic and neurobiologic compass points toward common signaling dysfunctions in autism spectrum disorders. J Clin Invest 119:747-754. CrossRef Medline

Levy D, Ronemus M, Yamrom B, Lee YH, Leotta A, Kendall J, Marks S, Lakshmi B, Pai D, Ye K, Buja A, Krieger A, Yoon S, Troge J, Rodgers L, Iossifov I, Wigler M (2011) Rare de novo and transmitted copy-number variation in autistic spectrum disorders. Neuron 70:886-897. CrossRef Medline

Liang P, Wan Y, Yan Y, Wang Y, Luo N, Deng Y, Fan X, Zhou J, Li Y, Wang Z, Yuan W, Tang M, Mo X, Wu X (2010) MVP interacts with YPEL4 and inhibits YPEL4-mediated activities of the ERK signal pathway. Biochem Cell Biol 88:445-450. CrossRef Medline

Lodato S, Rouaux C, Quast KB, Jantrachotechatchawan C, Studer M, Hensch TK, Arlotta P (2011) Excitatory projection neuron subtypes control the distribution of local inhibitory interneurons in the cerebral cortex. Neuron 69:763-779. CrossRef Medline

Lukas J, Bartkova J, Bartek J (1996) Convergence of mitogenic signalling cascades from diverse classes of receptors at the cyclin D-cyclin-dependent kinase-pRb-controlled $G_{1}$ checkpoint. Mol Cell Biol 16:6917-6925. Medline

Maillard AM, Ruef A, Pizzagalli F, Migliavacca E, Hippolyte L, Adaszewski S, Dukart J, Ferrari C, Conus P, Männik K, Zazhytska M, Siffredi V, Maeder P, Kutalik Z, Kherif F, Hadjikhani N, 16p11.2 European Consortium (2014) The 16p11.2 locus modulates brain structures common to autism, schizophrenia and obesity. Mol Psychiatry. Advance online publication. doi:10.1038/mp.2014.145. CrossRef Medline

Malatesta P, Hartfuss E, Götz M (2000) Isolation of radial glial cells by fluorescent-activated cell sorting reveals a neuronal lineage. Development 127:5253-5263. Medline

Martínez-Cerdeño V, Noctor SC, Kriegstein AR (2006) The role of intermediate progenitor cells in the evolutionary expansion of the cerebral cortex. Cereb Cortex 16 [Suppl 1]:i152-i161.

McCarthy SE, Makarov V, Kirov G, Addington AM, McClellan J, Yoon S, Perkins DO, Dickel DE, Kusenda M, Krastoshevsky O, Krause V, Kumar RA, Grozeva D, Malhotra D, Walsh T, Zackai EH, Kaplan P, Ganesh J, Krantz ID, Spinner NB, et al. (2009) Microduplications of 16p11.2 are associated with schizophrenia. Nat Genet 41:1223-1227. CrossRef Medline

McConnell SK, Kaznowski CE (1991) Cell cycle dependence of laminar determination in developing neocortex. Science 254:282-285. CrossRef Medline

Minshew NJ, Williams DL (2007) The new neurobiology of autism: cortex, connectivity, and neuronal organization. Arch Neurol 64:945-950. CrossRef Medline

Nakamura T, Gulick J, Pratt R, Robbins J (2009) Noonan syndrome is associated with enhanced pERK activity, the repression of which can prevent craniofacial malformations. Proc Natl Acad Sci U S A 106:15436-15441. CrossRef Medline

Nekrasova T, Shive C, Gao Y, Kawamura K, Guardia R, Landreth G, Forsthuber TG (2005) ERK1-deficient mice show normal T cell effector function and are highly susceptible to experimental autoimmune encephalomyelitis. J Immunol 175: 2374-2380. CrossRef Medline

Newbern J, Zhong J, Wickramasinghe RS, Li X, Wu Y, Samuels I, Cherosky N, Karlo JC, O'Loughlin B, Wikenheiser J, Gargesha M, Doughman YQ, Charron J, Ginty DD, Watanabe M, Saitta SC, Snider WD, Landreth GE (2008) Mouse and human phenotypes indicate a critical conserved role for ERK2 signaling in neural crest development. Proc Natl Acad Sci U S A 105:17115-17120. CrossRef Medline

Noctor SC, Flint AC, Weissman TA, Dammerman RS, Kriegstein AR (2001) Neurons derived from radial glial cells establish radial units in neocortex. Nature 409:714-720. CrossRef Medline

Noctor SC, Martínez-Cerdeño V, Ivic L, Kriegstein AR (2004) Cortical neurons arise in symmetric and asymmetric division zones and migrate through specific phases. Nat Neurosci 7:136-144. CrossRef Medline

Paul LK, Brown WS, Adolphs R, Tyszka JM, Richards LJ, Mukherjee P, Sherr EH (2007) Agenesis of the corpus callosum: genetic, developmental and functional aspects of connectivity. Nat Rev Neurosci 8:287-299. CrossRef Medline

Pinto D, Delaby E, Merico D, Barbosa M, Merikangas A, Klei L, Thiruvahindrapuram B, Xu X, Ziman R, Wang Z, Vorstman JA, Thompson A, Regan 
R, Pilorge M, Pellecchia G, Pagnamenta AT, Oliveira B, Marshall CR, Magalhaes TR, Lowe JK, et al. (2014) Convergence of genes and cellular pathways dysregulated in autism spectrum disorders. Am J Hum Genet 94:677-694. CrossRef Medline

Portmann T, Yang M, Mao R, Panagiotakos G, Ellegood J, Dolen G, Bader PL, Grueter BA, Goold C, Fisher E, Clifford K, Rengarajan P, Kalikhman D, Loureiro D, Saw NL, Zhengqui Z, Miller MA, Lerch JP, Henkelman RM, Shamloo M, et al. (2014) Behavioral abnormalities and circuit defects in the basal ganglia of a mouse model of 16p11.2 deletion syndrome. Cell Rep 7:1077-1092. CrossRef Medline

Pouysségur J, Volmat V, Lenormand P (2002) Fidelity and spatio-temporal control in MAP kinase (ERKs) signalling. Biochem Pharmacol 64:755763. CrossRef Medline

Pucilowska J, Puzerey PA, Karlo JC, Galán RF, Landreth GE (2012) Disrupted ERK signaling during cortical development leads to abnormal progenitor proliferation, neuronal and network excitability and behavior, modeling human neuro-cardio-facial-cutaneous and related syndromes. J Neurosci 32:8663-8677. CrossRef Medline

Qureshi AY, Mueller S, Snyder AZ, Mukherjee P, Berman JI, Roberts TP, Nagarajan SS, Spiro JE, Chung WK, Sherr EH, Buckner RL, Simons VIP Consortium (2014) Opposing brain differences in 16p11.2 deletion and duplication carriers. J Neurosci 34:11199-11211. CrossRef Medline

Rauen KA (2013) The RASopathies. Annu Rev Genomics Hum Genet 14: 355-369. CrossRef Medline

Roskoski R Jr (2012) ERK1/2 MAP kinases: structure, function, and regulation. Pharmacol Res 66:105-143. CrossRef Medline

Ross ME, Walsh CA (2001) Human brain malformations and their lessons for neuronal migration. Annu Rev Neurosci 24:1041-1070. CrossRef Medline

Samuels IS, Karlo JC, Faruzzi AN, Pickering K, Herrup K, Sweatt JD, Saitta SC, Landreth GE (2008) Deletion of ERK2 mitogen-activated protein kinase identifies its key roles in cortical neurogenesis and cognitive function. J Neurosci 28:6983-6995. CrossRef Medline

Samuels IS, Saitta SC, Landreth GE (2009) MAP'ing CNS development and cognition: an ERKsome process. Neuron 61:160-167. CrossRef Medline

Sanders SJ, Ercan-Sencicek AG, Hus V, Luo R, Murtha MT, Moreno-De-Luca D, Chu SH, Moreau MP, Gupta AR, Thomson SA, Mason CE, Bilguvar K, Celestino-Soper PB, Choi M, Crawford EL, Davis L, Wright NR, Dhod- apkar RM, DiCola M, DiLullo NM, et al. (2011) Multiple recurrent de novo CNVs, including duplications of the 7q11.23 Williams syndrome region, are strongly associated with autism. Neuron 70:863-885. CrossRef Medline

Satoh Y, Endo S, Nakata T, Kobayashi Y, Yamada K, Ikeda T, Takeuchi A, Hiramoto T, Watanabe Y, Kazama T (2011a) ERK2 contributes to the control of social behaviors in mice. J Neurosci 31:11953-11967. CrossRef Medline

Satoh Y, Kobayashi Y, Takeuchi A, Pagès G, Pouysségur J, Kazama T (2011b) Deletion of ERK1 and ERK2 in the CNS causes cortical abnormalities and neonatal lethality: Erk1 deficiency enhances the impairment of neurogenesis in Erk2-deficient mice. J Neurosci 31:1149-1155. CrossRef Medline

Schubbert S, Bollag G, Shannon K (2007) Deregulated Ras signaling in developmental disorders: new tricks for an old dog. Curr Opin Genet Dev 17:15-22. CrossRef Medline

Selcher JC, Nekrasova T, Paylor R, Landreth GE, Sweatt JD (2001) Mice lacking the ERK1 isoform of MAP kinase are unimpaired in emotional learning. Learn Mem 8:11-19. CrossRef Medline

Sherr CJ, Roberts JM (1999) CDK inhibitors: positive and negative regulators of $G_{1}$-phase progression. Genes Dev 13:1501-1512. CrossRef Medline

Tarabykin V, Stoykova A, Usman N, Gruss P (2001) Cortical upper layer neurons derive from the subventricular zone as indicated by Svet 1 gene expression. Development 128:1983-1993. Medline

Tartaglia M, Gelb BD (2010) Disorders of dysregulated signal traffic through the RAS-MAPK pathway: phenotypic spectrum and molecular mechanisms. Ann N Y Acad Sci 1214:99-121. CrossRef Medline

Weiss LA, Shen Y, Korn JM, Arking DE, Miller DT, Fossdal R, Saemundsen E, Stefansson H, Ferreira MA, Green T, Platt OS, Ruderfer DM, Walsh CA, Altshuler D, Chakravarti A, Tanzi RE, Stefansson K, Santangelo SL, Gusella JF, Sklar P, et al. (2008) Association between microdeletion and microduplication at 16p11.2 and autism. N Engl J Med 358:667-675. CrossRef Medline

Wu SX, Goebbels S, Nakamura K, Nakamura K, Kometani K, Minato N, Kaneko T, Nave KA, Tamamaki N (2005) Pyramidal neurons of upper cortical layers generated by NEX-positive progenitor cells in the subventricular zone. Proc Natl Acad Sci U S A 102:17172-17177. CrossRef Medline 